\title{
REMEMBERING POLAND: THE ETHICS OF CULTURAL HISTORIES
}

\section{William Gorski \\ Northwestern State University of Louisiana}

\begin{abstract}
Art Spiegelman's Maus, Cynthia Ozick's The Shawl, and Eva Hoffman's Lost in Translation and Exit into History are recent American texts that draw upon cultural histories of Poland to launch their narratives. Each text confronts and reconstructs fragments of twentieth-century Poland at the interactive sites of collective culture and personal memory. By focusing on the contested relationship between Poles and Jews before, during, and after World War II, these texts dredge up the ghosts of centuries-long ethnic animosities. In the post-Cold War era, wherein Eastern Europe struggles to redefine itself, such texts have a formative influence in re-mapping the future of national identities.
\end{abstract}

In The Other Heading: Reflections on Today's Europe (1992) Derrida tells us about the importance of histories as the basis from which a people, a culture, or a nation orients itself toward future directions. He states:

Like every history, the history of a culture no doubt presupposes an identifiable heading, a telos toward which 


\section{Ethnic Studies Review Volume 25}

the movement, the memory and the promise, the identity-even if it be as difference to itself-dreams of gathering itself; by taking the initiative, by going on ahead, in anticipation (92).

Derrida's concern about the textualizing of cultural history is voiced within the post-totalitarian moment. His musings address not only the forces of multinational economic unification in Europe but also the identity of separate nations, especially those of Eastern Europe struggling after Communist rule. In the 1990s those nations have been in the process of determining their orientation toward the future. What Derrida indicates is that a collective movement forward is intimately linked with how a people remembers its past.

\section{Introduction}

This article looks at recent American texts that draw upon cultural histories of Poland to launch their narratives. The narratives I will be examining are Art Spiegelman's Maus (1986, 1991), Cynthia Ozick's The Shawl (1989), and Eva Hoffman's Lost in Translation (1989) and Exit into History (1993). Each text gravitates toward uncovering and reconstructing fragments of history in twentieth-century Poland. This somewhat archaeological project is carried out at the interactive sites of collective culture and personal memory. The purpose of these recollections is, in part, to collapse the exclusionary plotlines of historical master narratives and to adumbrate the fullness of the past. In the words of Walter Benjamin, the task for inclusionary historiography is to render the past "citable in all its moments" (254). In the above text the subjects whose memories are being redrawn are natives of Poland who have emigrated to the United States. I group these texts together under a generic heading of a literature of remembrance, not of memory itself but of the work of remembering, an intellectual and emotional labor that is taken up as an individual and collective project.

This recollective project is distinctly postmodern in its attitude toward memory, which is contrary to what Lyotard conceives as modernism's impulse to forget. Lyotard states,

The very idea of modernity is closely correlated with the principle that it is both possible and necessary to 
break with tradition and institute absolutely new ways of living and thinking. We now suspect that this 'rupture' is in fact a way of forgetting or repressing the past, that is, repeating it and not surpassing it (76).

Lyotard's formulation is apposite my study because it points to the modernist positions and strategies the subjects take up in relation to their own memory. Vladek Spiegelman in Maus, Rosa Lublin in The Shawl, and Eva Hoffman in Lost in Translation experience rupture, trauma and alienation as social and political realities in their native Poland. Rather than programmatic shifts toward new futures, their forgetting of the past (except in Hoffman's case) stems from unconscious tactical maneuvers for psychological survival. However, these texts take up the postmodern work of restoring the lost or repressed fragments of the past.

If we can factor together the above statements by Derrida and Lyotard, we may come to some sense as to how the above texts under the heading of a literature of remembering, attempt to deposit the past into the present. But if we return to the idea that histories contain, presuppose, a telos toward which the identity of a culture is heading, then the above grouping also problematizes Derrida's proposition. That is, although the lost history and memory that each text strives to recover is Polish, the writers, their primary settings, and general audiences are American. The texts thereby accomplish a bridging of the two cultures, Polish and American, a considerable accomplishment given the several millions of Americans of Polish descent. However, to what end-toward what telos-do these textual reconstructions of history serve Polish culture, the future of Poland (or for that matter, the future of the United States)?

A segment of Derrida's The Other Heading was published in the January, 1993, PMLA under the title "The Other Heading: Memories, Responses, and Responsibilities." I would like to stress here Derrida's term "responsibility" as an important ethical feature in the act of setting forth history to generate a vision, a direction for the future. He asks:

And what if Europe were this: an opening onto a history for which the changing of the heading, the relation to the other heading or the other of the heading, were 


\section{Ethnic Studies Review Volume 25}

experienced as always possible? an opening and a nonexclusion for which Europe would in some way be responsible? for which Europe would be, in a constitutive way, this very responsibility? (91)

By "the other of the heading" Derrida refers to a European cultural identity that bears responsibility toward-and respects-the multiple differences such an identity would need to contain. Hence, regarding the texts under question here, we might ask whether their American-Polish textuality is responsible toward their internal othernesses. And more pointedly to the present moment, how do these historical accounts of Poland under the blights of poverty, Nazism, or communism foster the project of envisioning a new, post-Communist Poland?

\section{Exit Into History}

Eva Hoffman's 1993 Exit into History portrays the conditions in Eastern Europe in the wake of the Communist demise. In a chapter devoted to Poland, Hoffman directly addresses the matter of history and remembering:

The Poles have a tradition of tradition, a talent for historical memory-if only because for so long they had to live by it alone. They preserved their identity through memories of Poland, and through a potential ideal of Poland during more than a century of partitions, when the real Poland was wiped off the map. It's partly where the Poles' strong sense of themselves come from-this defiant maintenance of memory" (34).

Hoffman suggests that each new beginning "needs to construct its own history." This task, she indicates, is problematized by the last four and a half decades-"the brand-new past . . . . a chunk of history that was largely unwanted" (35). As commonly noted in postcolonial studies, initial attempts at cultural reconstruction after periods of colonization generally revert to former periods of putative national glory on which to base narratives of national identity. Within Hoffman's Lacanian framework, this return to a "further" past constitutes a repressive strategy regarding national memory. The Poles, she suggests, should resist the impulse to redact the recent and alien Communist layer in their historical memory. 
Further, regarding the strained history of Polish-Jewish relations, Hoffman asserts that this history is "largely unknown and untaught," that periods of prejudice and persecution are flanked by "long periods of fruitful coexistence" and that both cultures "cross-fertilized" one another (104). Yet the task of reconstructing this history, she states, "is bound to be convoluted and painful" (104). In order to promote the task of Polish reconstruction, Hoffman seems to enlist Zizek's historical application of Lacan's repressed:

(A)s the return of the repressed demonstrates ... the work of memory needs to be done before unconscious ideas stop exercising their force, before current reality can be faced on its own terms. Apparently history needs to be remembered before it can move on again. At the same time, history in Poland had to begin moving before it could accurately be remembered (104).

Indeed, Hoffman's title Exit into History suggests a movement forward into recuperation of the past-even of the amnesiaproducing Communist era. Placing Poland in the postmodern memory has this Janus-faced construct: a model of memory looking backward and forward, back to the moment of modernism and to the unthought of future-to the postmodern. Recuperation of the Polish past-whether that past is under silence, political erasure, or under trauma-enduced repression-(or personal memory shaped by an over-determining collective context) will make the present bearable and the future thinkable. Hoffman, in thus framing the cultural problem for the Western reader, fosters an understanding of a situation that might otherwise seem but a ripe field of opportunity for American investors.

\section{The Business of Remembering}

When Art Spiegelman's Maus appeared in 1986, it met with critical acclaim, especially for its use of the comic book genre to record personal memories of the Holocaust. Maus is the Holocaust survivor story of the author/narrator's father, Vladek Spiegelman, a textile merchant from Czestochowa, Poland, who with his wife, Anja, managed to endure the loss of family and the traumas of Auschwitz. Long-repressed memory provides narrative impetus. Vladek Spiegelman had never openly discussed the 


\section{Ethnic Studies Review Volume 25}

Holocaust with his American born son, Artie, and now Art attempts to retrieve the memory. My discussion here centers on the visual dimension of Maus. If we return to Derrida's directive that cultural histories need to be responsible to their internal others, we can assert that Spiegelman's comic book consistently keeps before the reader's eye the irreducibility of difference and otherness. Spiegelman's solution to the challenge of visually representing a multi-national narrative is to convert nationality into an allegorical figure. Allegory thus graphically maintains identity at the group level. The limits of this method are highly restrictive but reinforce the theme of the Holocaust, that is, the individual subsumed by the collective.

Two important narrative features that distinguish Spiegelman's text from other Holocaust memoirs are the comic book format and the allegorical representations of peoples as animals (Jews are mice, Germans are cats, Poles are pigs, Swedes are reindeer, etc.). The effect, or perhaps the message, of the allegory is to suggest the unalterable differences occurring at the collective levels of identity. Depicting human groups by one animal or another parallels the wearing of uniforms: identity is solidified and mobilized at the level of group affiliation, especially as identity is important in a multinational narrative bound up in the history of a world war. That Spiegelman's characters maintain their tribal masks decades after the war suggests that the current moment of globalization still operates through reductive tribal identities and, further, that the present moment is still bound to the former racial animosities that gave rise to the war. That is, the effects (read as lost memory) of former events are still producing offspring in the form of the de-humanized.

Spiegelman problematizes group membership on several fronts. The borders of otherness are sometimes drawn by nationality and sometimes by race. For instance, Americans are dogs. Yet, Americans are further defined by color: one is either a white dog or a black dog. Therefore, the status of the African race is subjugated to nationality; race is a subtext to nationality in the United States. The Jews, on the other hand, resist assimilation to national identity. The Jewish people, the focal group of the text, claim tribal identity above nationality. A Jew is first and foremost a Jew, even in America, as suggested by Spiegelman's 
self-portayal as a mouse. Another example of a people who resist the assimilation of national identity are the gypsies, who are humorously depicted as gypsy moths. The gypsies, like the Jews, are a diasporic people, and their maintenance of a position of otherness derives both from their own definition and from their host culture.

One might well ask what prompted Spiegelman to portray this tragic chapter in European history through a medium of popular culture and through the reductionist tropings of allegorized races. The allegorized figurings serve in part to historicize the narrative within the predominating fascism of the Third Reich and its imperialistic discourse of racial purity and superiority. The predatorial logic of the cat-mouse relationship is clearly extrapolated from Nazi thought, as the epigraphs to volumes I and $/ /$ explain: The Jews are undoubtedly a race, but they are not human (Hitler); and

Mickey Mouse is the most miserable ideal ever revealed.... Healthy emotions tell every independent young man and every honorable youth that the dirty and filth-covered vermin, the greatest bacteria carrier in the animal kingdom, cannot be the ideal type of animal Away with Jewish brutalization of the people! Down with Mickey Mouse! Wear the Swastika Cross. Spiegelman himself explains his allegorical choice for the Polish people as such:

I suppose the German epithet 'schwein' came to mind. I was looking for an animal totem outside the catmouse food chain that could fit into the 'Funny Animal' cartoon universe (Porky Pig came to mind) that could represent the Poles fulfilling the role of witness outside the central maelstrom. I wanted to reflect the Nazi hierarchy of dehumanization. Poles and Jews were both considered less than human, but the Slavic races were considered by Hitler as slaves for the Master Race; Jews until late in the war were consigned for immediate destruction, even their labor was a secondary consideration. By analogy pigs on a farm are raised for their meat; rodents are solely a threat to be exterminated. Somewhere in all my figurings were images of Polish 


\section{Ethnic Studies Review Volume 25}

sausages and the notion that an 'unkosher' animal would well reflect the animus between Poles and Jews which Vladek made all too clear to me. (letter) Spiegelman further darkens the implications of Polish antiSemitic sentiments by narrating how Poles carried on the Nazi's work of killing Jews even after the liberation.

Maus maintains a double narrative, tracking the stream of events in the present and in the past. In the present time narrative, Spiegelman portrays his visits to his father's home in Rego Park, Queens. The very first page of volume $/$ renders Vladek Spiegelman in terms of the estranging force of his personality. Art states, "I hadn't seen him in a long time-we weren't that close," and about Vladek's relationship with his second wife, Mala, "They didn't get along" (11). Though these statements do not blame Vladek for these discords, his angry outburst over the petty matter of wire hangers demonstrates that Vladek is the source of tension. However, in the interest of recording his father's survivor's tale, Art has decided to brave his father's often petulant and obsessive behavior. Structurally, each chapter begins and ends with the present-moment narrative, detailing domestic skirmishes between Vladek and Mala or repeating the age old strains between father and son. The second narrative strand, constituted out of Vladek's war memories, falls in between the parenthesis of the present. More than narrational device, the bracketing of memory demonstrates that the present contains the past.

Perhaps Spiegelman goes even further to suggest that the past imprisons the present. The dust jackets of both volumes graphically suggest the contiguity of history and the present moment. The back cover of volume / displays wartime Poland, partitioned by Russia and Germany; crossbones topped with mouseheads pinpoint the major concentration camps. Within this map a small streetmap of Rego Park has been inserted; the street blocks remind us of concentration camp barracks, and the railroad tracks of the Long Island Railroad cutting through the map's center echo the tracks which carted the Jews to their terminus at Auschwitz. On the back of volume II, the representation is inverted. That is, an aerial view of Auschwitz, with its block-like barracks and medial train tracks, quarantines within its borders a map of the Catskill Mountains, where Vladek vaca- 
tions. The image within the image sardonically suggests that the shadow of the death camps still haunts the contemporary "summer camps," the kosher resorts; in the Catskills, cats still kill mice. The figure of Vladek in his prison garb overlaps both mappings. Spiegelman thereby enunciates the various layers of his palimpsest; he visually collapses time to suggest that the parallax of historical hindsight is an illusion. The disease of the past is the symptom of the present.

Though Vladek has kept silent about his life in Poland, the silencing of personal memory has no direct connection with forgetting that memory. Silence appears to be an attempt to forget, even to destroy memory-to deny its original inscription and its residual trace. Vladek's first remove from the site of trauma occurs in 1946 when he boards a plane with several other refugees bound for Sweden. Though the refugees fear flying, Vladek quips,

So don't worry. Let the plane crash-at least we'll be out from Poland . . . . It was nothing anymore there for us after the war. Nothing" (I, 123, 124).

After his first wife's suicide in 1968, Vladek burns the journals containing Anja's Holocaust memories: "These papers had too many memories. So I burned them" (I, 159). The language here suggests that Vladek is attempting to destroy the memories themselves, rather than just the prompts of memory. So it is with reluctance that he collaborates with his son in the enterprise to remember, though he masks his resistance behind doubts regarding the project's commercial value: "Better you should spend your time to make drawings what will bring you some money" (I, 12).

But as much as Vladek wishes to repress Holocaust memory out of consciousness, his character and behavior attest to the active, persistent, and seemingly permanent nature of memory. I invoke here the standard Freudian paradigm of memory. As explained in "Recollection, Repetition and Working Through," the theory of repression asserts that both consciousness and the unconscious collude in negotiating a settlement around materials which, for one reason or another, must be censored from consciousness. However, energy that originally impelled the repression of a given content cannot be stanched, and, by associative 


\section{Ethnic Studies Review Volume 25}

processes, memory constructs alternative circuits for its expression. These circuits, namely substitutes and symptoms, deflect the conscious mind from remembering the repressed contents yet also provide a partial and unsatisfactory discharge of the imprisoned energy. And as Freud notes, the unsatisfactory nature of the substitution or metaphorical displacement gives cause for a return to the original scene of repression, to work consciously through the material the subject was previously unequipped to negotiate. The symptoms and substitutions that evidence the repression of Vladek's Holocaust nightmares are sudden eruptions of temper, disturbed sleep, an obsessive need to control his environment, an exaggerated thrift that complicates his relations to loved ones, a penchant for hoarding useless objects, dissociation from feelings, and a repetitive narration of recent petty events. This last symptom-substitution-is perhaps the most crucial, as Vladek is constantly sidetracked from his Holocaust narrative by endlessly renarrating the domestic skirmishes he encounters with his second wife, Mala (also a camp survivor), whom Vladek ironically represents as his oppressor. He has no sense of scale; for Vladek, his domestic strife seems as menacing and as totalizing as the regime at Auschwitz.

Perhaps Vladek's poor sense of scale, his disproportionate emotional reactions to minor events, also lends itself to the detailed narration he provides of life in prewar and Holocaust Poland. This narration of detail, in combination with the visual format of Maus, contributes to a parodic aura of documentation and authenticity. In several instances Vladek sketches for his son layouts of camp buildings, cross-sections of basement hideouts, diagrams of prison labor, and step by step instructions for shoe repair. His minute attention to these details attest not only to his capacious memory, but also to his interest in structuring and mastering the physical world. Further, Vladek's day to day account of camp life-particularly those instances wherein Vladek manages to cordon off his emotional life from the environment-provides the contemporary reader with a cultural study of concentration camps. Walter Benjamin, in his "Theses on the Philosophy of History" comments:

A chronicler who recites events without distinguishing between major and minor ones acts in accordance with 


\section{Gorski-Remembering Poland}

the following truth: nothing that has ever happened should be regarded as lost for history . . . only a redeemed mankind receives the fullness of its past . . . its past become citable in all its moments (254).

The citing and redemption of history within Maus occur at the expense of the heroic and the monumental, tendencies which mark out the terrain of Modernism. Vladek's minor acts of heroism do not serve to diminish the reigning terror of the Third Reich; they serve Vladek's continuing need to stave off the terror lodged in memory. As Lawrence Langer cautions,

Only through the invention of a mythic narrative 'afterwards' can we reconstruct an idiom to change their death from a 'forgettable' (because unbearable) occasion into a memorable one (270).

Spiegelman also seems to deflate the modernist psychoanalytic notion that remembering trauma induces catharsis and hence a return to the realm of normalcy. Instead, the conscious and present containment of memory suggests a postmodern memory noted for its sense of simultaneity and coextension. Vladek's remembrance conveys no therapeutic effect. It would seem that the Holocaust has not only inscribed but tattooed the memory in some permanent way. Just as we repeatedly recognize the numbered tattoo on Vladek's forearm, the tattoo of memory cannot be erased, and any attempt to forget or cover over results only in blistering eruptions of the original trace. Maus's comic book survivor's chronicle restores and restories the past, but makes no claims to purging its demons.

Poland, then, becomes a primal scene that is repressed and then returns as the Real in Lacanian terms. Poland maps out the original trace of memory-personal memory inscribed by a culture of extermination. Transposed in an inter-generational narrative set in America, Poland is the irretrievable motherland (and mother), the site of primary union and disjuncture. Poland's status as the place to which return is impossible, yet which always returns through memory, further suggests Lacan's fundamental assessment of human existence. In the words of Ellie RaglandSullivan,

The devastating loss of symbiosis [fusion] is repressed and displaced, but symbolically felt by its effects. This 
is why Lacan speaks ironically of the faut/faux du temps, playing on the idea that self-revelation only comes in the unfolding of a person's "epic" in time, but also on the fact that chronological time is false. The primordial separation drama creates a repressed void in being which never ceases to echo (270).

My consideration of Maus in the light of Lacan's developmental models in no way minimizes the particular historical contingencies of the Holocaust. My point is that Maus's particular bordercrossings-in time, space, and genre-also raise important questions about identity, ethnicity, memory, and culture. The separation drama that Spiegelman stages marks out voids between child and parent, between Poles and Jews, and as suggested by the animal figurings, between human being and racial being.

Spiegelman ends Maus with an image of the gravemarker shared by Vladek and Anja, now both dead. This particular iconography speaks to Spiegelman's memorializing intent; that is, Maus is a textual monument (as opposed to the monumental) to the Holocaust. James E. Young, in theorizing about Holocaust monuments, comments that such monuments" "fusion of public art and popular culture" is produced specifically to be historically referential, to lead viewers beyond themselves to an understanding or evocation of events $(69,99)$.

The more private (yet public) graphic gravemarker in Maus is positioned both inside and outside of the comic text. That is, the headstone's position allows its referents to participate in the remembered world of the text and also in the world outside the text. This world outside the text is the empty margin-itself a border between inscribed textual space and the contextualizing space of the reader. The preservation of memory, the image seems to suggest, is the active awareness of this borderland, situated between text and reader, present and past, story and memory, the dead and the living, Poland and America.

As a memoir that bears enormous implications as a historical narrative, we might conclude that Maus's depiction of wartime Poles is rather one-sided in a negative vein. Though Maus does much by way of resurrecting a fragment of European history-particularly Jewish and Polish-it seems to do so without regard for the telos of the cultures represented. However, to be 
fair to Spiegelman, no culture-American included-escapes the captivity of his satire.

\section{Alternative Histories}

Whereas Maus visually offers a history of totalitarian horror that the survivor would rather forget, Cynthia Ozick's The Shawl presents a survivor which, in theorizing its own complex hybrid status as memory and virtual memory, demonstrates the impossibility of both remembering and forgetting one fatal segment of Polish, Jewish, and European history. And whereas Maus visually produces a narrative schizoid split between collective representation and personal memory, The Shawl produces its own schizoid narrative in generating memory based on experience that never occurs.

Ozick's novella, The Shawl, comprised of two related stories, "The Shawl" and "Rosa," portrays Holocaust survivor Rosa Lublin as she perpetually hovers over the fields of memory, alighting on some segments and avoiding others. She creates alternative histories of her own memory; she creates an alternate memory that takes on a life of its own. This alternate memory becomes as indestructible as memory generated via experience. Rosa's present day existence in a Miami boarding hotel is a refuge from life, a sort of limbo in which she recreates her infant daughter, Magda, who was murdered in the camps.

"The Shawl," the short story which begins the novella, is set in a nameless land, in a nameless camp (which, however, as we may infer from Rosa's last name, is probably Maidenek, the camp on the outskirts of Lublin). Salman Rushdie's sentence, "My story's palimpsest country has, I repeat, no name" (88), describes well a similar status for Ozick's Poland. As a historical site, wartime Poland is already appropriated and overwritten by its captors. In some instances Polish linguistic geography is erased and denied its own name. For example, Auschwitz has replaced the Polish town named Oswiecim in a permanent way, first as a German appropriation and second as a Jewish memorial.

The anonymity of the place echoes the larger anonymity to which Rosa and all camp prisoners were subjugated. A name suggests identity, an entry into the shared world of language through which we are named and identified and through which 


\section{Ethnic Studies Review Volume 25}

we continue to identify ourselves. Moreover, a name creates a sense of belonging to self and others. Naming, we could say, produces community-a shared reference. In the concentration camps, however, the names of the prisoners were stolen from them; they were re-christened with a tattooed forearm. The senseless hours the prisoners stood for appel, the guards checking and rechecking the roll of seven-digit numbers, stresses the Nazi obsession with naming (or, more precisely, with numbering). The issuing of serial numbers reveals the Nazi strategy of reifying the prisoners-that is, of converting citizenry to property, to units of production. The invocation of the prison-issued numbers, hour after hour, sardonically hearkens back to Adam and his God-granted charge to name the beings of creation. I dwell upon this specific feature of camp-life as it demonstrates the oppressors attempt to obliterate the associative tissue of memory, but also provides the setting in which Rosa's baby girl, Magda, is discovered by an S.S. guard and summarily murdered. Prior to this scene Magda has been speechless. Since mother and child have been on a death march, and Rosa can produce no milk, Magda has ceased to produce her childish speech. Ozick is perhaps suggesting a primary linkage between nurture and speech, love and language. Yet as Magda's need for nourishment persists, Rosa gives her shawl to the child to suckle on. The shawl doubles then as the mother-it becomes a substitute mother, an actual though metaphorical replacement.

The metaphorical status of the substitute is disseminated throughout The Shawl. Specifically Ozick repeatedly employs a chain of metaphors in order to name persons or things. For instance the following chain of four metaphors describes Rosa's dried up breasts: "The duct-crevice extinct, a dead volcano, blind eye, chill hole" (4). Other chains seem less negative, such as Magda's face peeping through the shawl: "a squirrel in a nest, safe, no one could reach her inside the little house of the shawl's windings . . . a pocket mirror of a face" (4). The insistence on metaphorical naming and renaming verges on narrational excess. However, if we focus on the rhetorical function of the metaphor as a substitute (shawl for mother), then the metaphor gains clarity as a compensatory modality for the fundamental lack that the camp prisoners experience. The mother's desire to 
supply nurture-to give from her body-is perversely sublimated to the realm of discourse. Breast-feeding is substituted by metaphor, epithet, and poetry, none of which can sustain her daughter's body. Although the high instance of metaphors tends to poeticize the text and seems ironically to produce a cultural poetics of the concentration camp, I would argue that Ozick's stylistics target another agenda. That is, her primary rhetorical strategy-that of naming through a chain of metaphors-suggests that one substitution is not enough to rename the subject, not sufficient to restore the subject to a name once the name has been repressed. The bounty of metaphor signals, instead, a profound sense of lack in the symbolic domain. In this "place without pity," stripped of culture and identity, the reliance on metaphor becomes a survival tactic. Yet it is metaphor-as poetry or as substitution (shawl)-that staves off the horrors of virtual interment. Therefore, Ozick's ironic poetics suggest a lyrical impulse of consolation, a means of denying the overwhelming denial of life that constituted every strategy of camp life.

The shawl is also a miniature palimpsest, a woven text. Rosa uses it to hide Magda, to mask her daughter's existence, for the only way to maintain one's life in the camp is to submit to the personal death of having identity erased, to become the property of the evil empire, to accept the anonymity of number. Like Poe's purloined letter, the shawl's presence, absence, possession, or loss generates narrative movement.

The pivotal event of the story occurs when Rosa's fourteen year old niece, Stella, steals the shawl (i.e., appropriates the mothering she also needs) from the sleeping Magda. When Magda awakens to discover the shawl's absence, she wanders into the yard during the appel to look for her substitutional mother. Magda shatters her long-held silence by crying out "Maaaa," (8) the utterance which solidifies the metaphorical connection between mother and shawl. Further, Magda's "Maaaa" reinscribes Rosa with the name of mother. She has restored Rosa to her function as life-giver and nurturer. Moreover, since "ma" constitutes the first syllable in Magda's own name, its invocation is another way of saying "me." The symbiosis of mother and daughter exemplifies Lacan's developmental paradigm of the mirror stage, wherein the child discovers its separate existence in 


\section{Ethnic Studies Review Volume 25}

relation to the mother's body, "a pocket mirror of a face." And within the terms of palimpsest history, Magda represents the return of the real, that which cannot be erased-that imaginary layer of instinct and emotion erupting through the imposed symbolic layers of the palimpsest. In her innocence Magda has violated the principal dictate of tyrannical bureaucracy: she supersedes abstract number by exercising that primordial privilege of human naming. Yet for Magda's radical utterance she must pay. Her cry of "Maaaa" attracts an S.S. officer, who picks up the child and tosses her through the air to land on the electrified fence. At the sight of her daughter flying through the air, Rosa stifles her own impulse to cry out by stuffing her mouth with the now recovered shawl. Like an inverted mirror image, the shawl that once served as substitute mother-nurturer will now be transformed into a substitution for a dead daughter.

The same shawl reappears in "Rosa." The action of this story occurs in Miami, some thirty years after the war. Rosa has recently left Brooklyn after taking an ax to the secondhand shop she owned. In her one-room quarters in a cheap hotel, Rosa unpacks the shawl that Stella has mailed to her. Rosa needs the physical artifact of the shawl to invoke the reality of her daughter's fictive presence. Though Magda has been dead these thirty years, Rosa has sustained more than mere memory of Magda through various fictions: Magda the physician, Magda the Columbia University professor. In each incarnation this spectral Magda is a successful young professional. This way, through endless narratives that have no basis in fact, Rosa has created alternative histories. Salman Rushdie claims, "All stories are haunted by the ghosts of the stories they might have been" (116). The ghost stories of Magda, what her life might have been, are Rosa's palimpsest that she constructs to cover over the tragic facts of "The Shawl."

Mixed in with alternative histories, however, are Rosa's oftnourished memories of her early life with her parents in Warsaw. Just as Rosa replaces the fact of Magda's death with fictions of her presence, she also fences out the realities of modern America with memories of prewar Poland. These memories recuperate the status her family prided themselves on before the Nazi onslaught. She scoffs at the Americans "who call her refugee" 
and lump her together with ghetto Jews (20). As she says to the immigrant Persky, "Your Warsaw is not my Warsaw" (22). In Rosa's remembrances, Poland is an amalgam of high culture, beauty, literary accomplishment, her father a scholar; her mother a poet.

In school she had read Tuwim: such delicacy, such loftiness, such Polishness. The Warsaw of her girlhood: a great light; she switched it on, she wanted to live inside her eyes. . . . Cultivation, old civilization, beauty, history! Surprising turnings of streets ... . unexpected and gossamer turrets, steeples, the gloss, the antiquity! Gardens. Whoever speaks of Paris has never seen Warsaw. Her father, like her mother, mocked at Yiddish; there was not a particle of the ghetto left in him, not a grain of rot. Whoever yearns for an aristocratic sensibility, let him switch on the great light of Warsaw (20-21).

Rosa's claims on her father's sublimated ethnicity are further buttressed by his sense of patriotism:

My father was never a Zionist. He used to call himself a 'Pole by right.' The Jews, he said, didn't put a thousand years of brains and blood into Polish soil in order to have to prove themselves to anyone (40).

Rosa's mother also seems to have lost her ethnic Judaism in favor of the stronger strains of Polish culture, wanting to convert to Catholicism and as a poet, her mother's Polish was "very dense. You had to open it out like a fan to get at all the meanings" (42). These topographical anchorings of the cultural, racial, and nationalist aspects of the Polish subject make it all the more difficult for Rosa to reconcile herself to her exile in Miami. Since that earlier Poland has been destroyed, she seeks eternal refuge in the memory of the fatherland and the mother tongue.

Rosa theorizes to Persky the basis for her condition of exile. She employs a threefold partitioning of history to explain how experience has been inscribed in memory: "the life before, the life during, the life after" (58). The middle phase-the life during-is marked out by its permanence. The lives of before and after, while they may leave a trace in memory, do not have the same durability of inscription. Rosa explicates her hypothesis in 


\section{Ethnic Studies Review Volume 25}

two ways:

1) The life after is now. The life before is our real life, at home, where we was born . . . . [And during,] this was Hitler; 2) Before is a dream. After is a joke. Only 'during' stays. And to call it a life is a lie (58).

The duration of the Holocaust, therefore, alters the concept of memory as trace. Holocaust memory is categorically different, as Lawrence Langer argues, imposing its indelible inscription over both the before and after of passing time (263-273). The staying power of the "during" seems to elevate Holocaust memory to a fifth dimension of time, eternal recurrence or perpetual repetition of trauma. The events contained in the short story "The Shawl" constitute Rosa's "during." It is the witnessing of Magda's death that Rosa actively seeks to deny. She attempts instead to construct an alternative line of living time in defiance of the black hole of the Holocaust that continues to suck in and devour the before and after. Yet as much as Rosa insists on the reality of her fictional daughter, the end of the narrative suggests, provisionally, that Rosa may relinquish the spectral Magda to live in relation to the present.

This shift occurs when Rosa takes the shawl out of its box and envisions Magda at the age of sixteen. Rosa then writes a long letter to Magda in which she recounts how she and her parents were pressed into the Warsaw ghetto. Once again Rosa delineates family status: "My father was a person of real importance, and my tall mother had so much delicacy and dignity" (68). Yet their entry into the ghetto represents a fall, being lumped together with the mere "working class," with "teeming Mockowiczes and Rabinowiczes ... . with all their bad-smelling grandfathers and their hordes of feeble children" $(68,66)$. Rosa describes how she used to relate fragments of her ghetto history to the customers who frequented her Brooklyn shop. Like Coleridge's Ancient Mariner, she is compelled to repeat her narrative over and over, though Rosa's narrative lacks the former's purpose of expiation and instruction. The customers do not understand; Rosa is never heard.

In chronicling these events for Magda, her addressee is leading toward a confrontation between actual and fictive histories, toward being able to hear herself. The pocket mirror of a 
face-Magda's visual power or reproduction-takes on the auditory analog of an echo chamber. The mirror stage appropriate to the infant Magda would be reenacted for Rosa: by hearing and seeing herself through the empty reflection of the absent Magda, Rosa is confronting her own narcissism. If Rosa continues to tell her story to Magda, she must logically arrive at the moment of Magda's death on the electrified fence. Perhaps remembrance of the trauma in all its pain will mitigate the indelible "during" as well as the alternative lives Rosa has constructed to override (overwrite) the Nazi palimpsest.

But Ozick ends The Shawl on an indeterminate note with Persky coming up to Rosa's hotel room. Rosa removes the shawl from the telephone receiver, and Magda vanishes: "Magda was not there. Shy, she ran away from Persky. Magda was away" (70). Though the prognosis is indeterminate, it is hopeful. The negotiation between memory and fantasy has begun. Through a fictional narrative-Magda's continued existence-Rosa has created a memory more real to her than her current life can dislodge. Yet through the narrating of actual memory Rosa at the point of remembering Magda's death will have to dissolve, to kill even, the alternative daughter she has invented. If permitted the indulgence to speculate on events beyond the boundaries of the text, I would suggest that Rosa's appointment with forestalled mourning, if it does not overwhelm and cripple her, may well lead to her entry into a new world. By "killing" her daughter, Rosa will give birth to herself.

This alternative future based on the hope built into Freud's model of memory is not, however, what Ozick offers. Ozick's pastiche of cultures, memories, and fabrications suggests the limitations of the psychoanalytic model of catharsis. Instead a postmodern memory is offered, one that seems to disclose a subjectivity (as well as narrative and nationality) that is non-centric. Its inclusion of radically different otherness militates against sequential time, against cause and effect, and against a model of healing that attempts to restore the subject to itself by therapeutic reintegration of repressed memory.

Ozick's importation of Polish/Jewish culture and history into her American text also brings into view an implicit critique of mainstream American culture. As in Maus, Rosa's remembrance 


\section{Ethnic Studies Review Volume 25}

of a now extinct haven within Polish culture registers a larger existential alienation indicative of postwar cultural logic. However The Shawl projects a slim redemptive hope that American culture offers-to begin again, to rebuild a shattered life. This potential, as borne out by other immigrant narratives, speaks to the further potential within United States history to absorb the foreign subject-the refugee-within its borders, which, dialogically, necessitates an expansion and alteration of its own cultural boundaries.

\section{Memory as Cultural Self}

Eva Hoffman's Lost in Translation moves this study beyond recent American literary approaches to World War II into Poland's Communist era. Hoffman recounts her postwar childhood in the seemingly idyllic Cracow, her family's emigration to Vancouver when the Communists allow Jews to leave Poland in the late 1950s, and her later adult assimilation into American culture. These three movements are reflected in Hoffman's threefold narrative arrangement: "Paradise," "Exile," and "The New World." This periodicity of personal history is resonant of Rosa's before, during, and after. Similar to Rosa's Warsovian childhood, Hoffman's "Paradise" is a charmed one, filled with happy family relations and an entry into the world of literature and imagination. Hoffman's "Exile" (the during), though in no way comparable to the trauma of the Holocaust, is nevertheless marked out by the loss of native culture and language. These losses result in alienation from social discourse as well as from her internal referencing; she occupies the marginalized zone of the immigrant. And the posited "New World" to which Hoffman assimilates slowly is yet overshadowed by her sense of exile.

Lost in Translation is memoir devoted to representing the process of memory-loss and its recuperation. And here I employ the term memory not as stored information but as the cohering processes of language, emotion, and sensation inscribed in childhood and constitutive of identity. Hoffman passionately articulates the motivating logic for her childhood recollections in the first section, "Paradise," a childhood marked not only by its intense affections, sharply defined sensations, and feelings of playfulness and wonder but also by the cruel, irrational taunts of 


\section{Gorski-Remembering Poland}

anti-Semitism, registered both locally and nationally:

No, I'm no patriot, nor was I ever allowed to be. And yet, the country of my childhood lives within me with a primacy that is a form of love... despite my knowledge of our marginality, and its primitive, unpretty emotions (74).

Poland has given her "language, perceptions, sounds" as well as first loves and the "furrows of reality" (74). Her roots as a social and psychological being have been nurtured by this first food of impressions, and moreso the topographical anchorings of Poland have delineated an organic relation to the earth:

No geometry of the landscape, no haze in the air, will

live in us as intensely as the landscapes that we saw as the first, and to which we give ourselves wholly, without reservations (74-75).

Insofar as Hoffman's memoir recapitulates the generic stages of the Bildungsroman, her translation project is one of continual return to this Eden of Cracow:

All we have to draw on is that first potent furnace, the uncomparing, ignorant love, the original heat and hunger for the forms of the world, for the here and now (74).

The terms "uncomparing," "ignorant," and "here and now" all suggest a return to innocence, which derives its potency from a condition of internal unity, before the mark of difference produces an alienating fissure within the subject (and hence with the subject's relation to the world).

This return, however, cannot be translated into space-time reality, as Hoffman demonstrates in her first return trip to Poland in 1977 at the age of thirty-one. Poland is still under Communist rule, and aside from the visible effects of pollution, Cracow seems remarkably unchanged. Yet the familiar landscapes and social impressions fail to evoke previously felt potency. Proust's narrator concluding Swann's Way seems to echo in the background of Hoffman's text:

How paradoxical it is to seek in reality for the pictures that are stored in one's memory, which must inevitably lose the charm that comes to them from memory itself and from their not being apprehended by the senses. 


\section{Ethnic Studies Review Volume 25}

The reality that I had known no longer existed(325).

During her almost twenty year absence from Polish culture, she has decidedly acquired a hybrid-self, a tenuous negotiation between American and Polish influences. She formulates the tensions of her precarious balancing act in contrast to Theodor Adorno, "who warned his fellow refugees that if they lost their alienation, they'd lose their souls" (209). In other words don't allow a new culture to efface your origins-don't become a walking palimpsest. Hoffman prefers a less oppositional stance, one that allows her to lose her alienation without losing herself. And her return to Cracow proves that she has maintained to some extent her Polish self, yet the distances of time and culture have ineluctably interceded.

What exonerates Hoffman from cliché realization-you can't go home again-are the implications this journey has for relation to the past and present:

To some extent, one has to rewrite the past in order to understand it. I have to see Cracow in the dimensions it has to my adult eye in order to perceive that my story has been only a story, that none of its events has been so big or so scary. It is the price of emigration, as of any radical discontinuity, that it makes such reviews and rereadings difficult; being cut off from one part of one's own story is apt to veil it in the haze of nostalgia, which is an ineffectual relationship to the past, and the haze of alienation, which is an ineffectual relationship to the present (242).

Although it is not quite valid to compare the subject of an autobiography to a biographical subject (such as Vladek Spiegelman) or to a fictional character (such as Rosa Lublin), I would like to draw such a comparison, as it may provide an instructive conclusion. I want to suggest that Hoffman is able to return home, both figuratively and literally, because the radical discontinuity she suffered via emigration was comparatively easy. Though her girlhood is darkened by anti-Semitism, the greater share of her memory is positive. Vladek and Rosa, however, suffer trauma and alienation on native soil. Since their radical discontinuity begins in Poland, the project to recuperate lost memory and culture is both a problem and a necessity. 


\section{Conclusion}

Yet a greater inference to be drawn from Lost in Translation is the comparatively open and thorough depiction Hoffman renders regarding the interplay of cultures, identity, and memory. Her engagements of Poles with American culture and the Americanized Pole's return to contemporary Poland point toward an ever-expansive (yet minutely attended and attuned) fluidity occurring within national identities. Hoffman, perhaps because of the site she occupies as Jewish-Polish-American in the postwar(s) era, performs the broadest and most constructive work of any of the writers studied here. Her work enacts for a Western readership a journey from innocence to experience that implicates the amalgam of several identities within one subject. Unlike Spiegelman's Maus, which insists on tribal difference as its organizing principle, Hoffman demonstrates a singular capacity for integration, or inclusion, of the past and present, Jew and Pole, East and West.

The common chord the above texts strike is the evocation of Poland as a site of unfinished business between nations, tribes, races, and intra-psychically for survivors. As Hoffman notes, both Nazi and Communist regimes constituted a stoppage of sorts for Polish history, and now the Poles must reconstitute their history in the post Cold-War era. The American writers herein discussed have helped in this effort, at least so far as our current frame of reference is a multi-national, global one. Just as the remembrance of the Holocaust has become an American project (the museums in Washington and Los Angeles; Steven Spielberg's on-line Holocaust archive), a project to preserve Jewish memory and to prevent recurrence, so too with the current focus on Eastern Europe it becomes a site not just for capital investment but of cultural interest for Americans, especially insofar as the threads of heritage are recognized. 


\section{Ethnic Studies Review Volume 25}

\section{Works Cited}

Benjamin, Walter. Illuminations. New York: Random House, 1988.

Brooke-Rose, Christina. "Palimpsest History." Interpretation and Overinterpretation. Ed. by Stefan Collini. Cambridge: Cambridge UP, 1992.

Derrida, Jacques. The Other Heading: Reflections on Today's Europe. Trans. by Pascale-Anne Brault and Michael B. Naas. Bloomington: Indiana UP, 1992.

- "The Other Heading: Memories, Responses, Responsibilities." PMLA 108 (1993): 89-93.

Freud, Sigmund. The Standard Edition of the Complete Psychological Works. Ed. James Strachey. 23 vols. London: Hogarth, 1961.

Hoffman, Eva. Exit into History: A Journey Through the New Eastern Europe. New York: Viking, 1993.

- Lost in Translation: A Life in a New Language. New York: Dutton, 1989.

Hutcheon, Linda. The Politics of Postmodernism. London: Routledge, 1989.

Klinkenborg, Verlyn. The Last Fine Time. New York: Knopf, 1991.

Langer, Lawrence. "Memory's Time: Chronology and Duration in Holocaust Testimonies." The Yale Journal of Criticism, 6.2 (1993): 263273.

Lyotard, Jean-Francois. The Postmodern Explained: Correspondence 1982-1985. Trans. by Don Barry, Bernadette Maher, Julian Pefanis, Virginia Spate, and Morgan Thomas. Minneapolis: $U$ of Minnesota P, 1993.

Ozick, Cynthia. The Shawl. New York: Vintage, 1990.

Proust, Marcel. Remembrance of Things Past, I: Swann's Way. Trans. by C. K. Scott Moncrieff. New York: Random House, 1934. 
Ragland-Sullivan, Ellie. Jacques Lacan and the Philosophy of Psychoanalysis. Urbana: $U$ of Illinois P, 1987.

Reiss, Timothy J. "Literature and the Idea of Europe." PMLA 108 (1993): 14-29.

Rushdie, Salman. Shame. London: Jonathan Cape, 1885.

Spiegelman, Art. Maus: A Survivor's Tale, I: My Father Bleeds History. New York: Pantheon, 1986.

- Maus: A Survivor's Tale, II: And Here My Troubles Began. New York: Pantheon, 1991.

- Letter to author, June 20, 1994.

Young, James E. "The Biography of a Memorial Icon: Nathan Rapoport's Warsaw Ghetto Monument." Representations 26 (1989): 69-106. 